\title{
Geoelectrical Assessment of the Impact of the llokun Dumpsite, Ado- Ekiti Southwestern Nigeria, on Surrounding Groundwater Aquifers
}

\author{
T. A. Lateef ${ }^{1}$, Akinola B. Eluwole $^{2}$, Dare J. Adewa ${ }^{1}$ \\ ${ }^{1}$ Department of Physics, Ekiti State University, Ado - Ekiti, Nigeria. \\ ${ }^{2}$ Department of Geology, Ekiti State University, Ado - Ekiti, Nigeria. \\ E-mail address: akinola.eluwole@eksu.edu.ng
}

\section{Keywords: Geoelectrical Assessment, llokun Dumpsite}

\begin{abstract}
The area around the Ilokun dumpsite, Ado-Ekiti was investigated with the aim of establishing the possible impact the contaminant plumes emanating from the dumpsite have on the subsurface aquifers. The Vertical Electrical Sounding (VES) field technique of the electrical resistivity method was adopted for the study, and the half-electrode spacing $A B / 2$ varied from 1 to $65 \mathrm{~m}$. A total of eight VES stations were occupied and a control VES point was located on the refuse dump. The VES data were interpreted quantitatively by partial curve matching and computer iteration, after which the geoelectric parameters were used to evolve a 2-Dimensional geoelectric section beneath the study area.

The weathered layer beneath the control VES point was identified to be the aquifer unit, but the anomalously low resistivity of $18 \mathrm{ohm}-\mathrm{m}$ within the unit was interpreted as an evidence of pollution from conductive contaminant plume. The geoelectric section beneath VES 1 to 7 delineated four layers, these include the topsoil; the weathered layer; the fractured basement and the fresh basement. The resistivity and thickness range of the layers are $177-399 \mathrm{ohm}-\mathrm{m}$ and $0.7-1.2$ $\mathrm{m} ; 29-842 \mathrm{ohm}-\mathrm{m}$ and $1.0-3.4 \mathrm{~m} ; 16-446 \mathrm{ohm}-\mathrm{m}$ and $4.5-45.5 \mathrm{~m}$; and $289-2144 \mathrm{ohm}-\mathrm{m}$ respectively. The fractured layer constitutes the main aquifer unit beneath the seven VES points, but the anomalously low resistivity of $16-47 \mathrm{ohm}-\mathrm{m}$ within the fractured layer beneath VES 4, 5, 6 and 7 is suspected to be as a result of pollution from conductive contaminant plume emanating from the dumpsite. The fractured layer beneath VES 2 and 3 which does not show any evidence of pollution yet is at a risk of being contaminated, due to its interconnection with the polluted zone.
\end{abstract}

\section{INTRODUCTION}

Solid wastes are the unwanted or useless solid materials generated from combined residential, industrial, and commercial activities in a given area. It may be categorized according to its origin (domestic, industrial, commercial, construction or institutional); according to its contents (organic material, glass, metal, plastic paper. e.t.c.) or according to hazard potential (toxic, non-toxin, flammable, radioactive, inflections. e.t.c) (Nwosu, 2009). According to Basel convention, "Solid wastes are substances or objects which are disposed or are intended to be disposed or are required to be disposed by the provision of National law."

Nigeria, like most developing countries, is paralyzed by serious financial constraints in undertaking a program of providing adequate quality or potable water to all her inhabitants as many depends on pipe borne water and well water, this made people to resort to groundwater exploration for domestic, agricultural and industrial purposes. Various socio-economically developed activities caused by population pressure with their attendant waste generation and improper management of these wastes continue to threaten water quality (Hussain et al., 1989)

Solid waste management has emerged as one of the greatest challenges facing state and local government environmental protection agencies in Nigeria. The volume of solid waste being generated continues to increase at a faster rate than the ability of the agencies to improve on the financial and technical resources needed to parallel this growth. Solid waste management is characterized by inefficient collection methods, insufficient coverage of the collection system and 
improper disposal of solid waste (Ogwueleka, 2003). As a result, most of these wastes, indiscriminately dumped in landfill site, find their way into water course either through run-offs during rain (into surface water) or by leachate-percolation from the wastes which naturally infiltrates into the groundwater depending on the stratigraphy of the area hence, making it unwholesome for use (Badmus, et al., 2001)

Unarguably, uncontrolled citing of boreholes as the source of potable water in most of our urban and rural communities as the government seemingly no longer provides the populace with water has become a serious challenge. However, maintaining a potable groundwater supply that is free from microbial and chemical contaminants is far from reality in most of our urban centers, and particularly, Ado-Ekiti, Nigeria due to poor waste disposal and management practices. The challenge is worsened by the fact that there are inadequate trained waste disposal workers and equipment, poor waste collection, sorting and disposal sites without regards to the local geology and hydrogeology of the area. All these contribute significantly to the groundwater contamination as well as soil quality (Bou-Zeid and El-Fadel, 2004). Some of the major effects of poorly managed dumpsite are leachate formation, disease spread, attraction of Vermin, mosquito breeding, strong odour spread in the entire area, gas formation e.g methane, increase in soil acidity and alkalinity and destruction of the ecosystem (Hussain et, al.1989)

In Ado-Ekiti, Nigeria, groundwater serves as a major source of potable water for the population at large. Since the quality of groundwater is more important than its quantity, there is need to study the possible effect(s) of the leachate emanating from the Ilokun dumpsite on the surrounding aquifer unit(s), hence this study.

\section{SITE DESCRIPTION AND GEOLOGY}

The dumpsite is located within Longitude 5.27 and 5.30 and Latitude 7.65 and 7.66 in decimal degrees respectively (Figure 1). It is situated along Ado-Iworoko road and it has a good accessibility. There is an Ebira community within the study area. The composition of Ilokun dumpsite are organic materials, polythene and plastic materials, meta scraps, animal wastes etc.

The geology of the dumpsite is that of the Basement Complex of southwestern Nigeria Rahaman (1988) and it has migmatite as its main rock unit (Figure 2). This rock unit manifests as surface outcrops around the study area. The area falls within the tropical rainforest vegetation and also characterised by short dry and long wet seasons.

\section{MATERIALS AND METHODS}

The electrical resistivity method of geophysical prospecting was adopted for this research. The method involves the supply of direct current ( D.C.) or low-frequency alternating current into the ground through a pair of current electrodes. The ratio of voltage measured to current measured by the ammeter results to resistance and resistivity is gotten from the product of resistance and length or electrode spacing.

A total of eight (8) Vertical Electrical Sounding (VES) measurements were taken on and around the dumpsite. The first VES was the Control VES which was taken on the dumpsite to delineate its resistivity properties and to identify the contaminant plume. The results of the Control VES were compared with the results of the other seven (7) VES points around the dumpsite to assess the extent of contamination. Field resistance measurements were taken using CAMPUS OMEGA terrameter. The apparent resistivity values obtained were manually plotted against their respective current-electrode spacing values $(A B / 2)$ on a log-log graph. The curves were interpreted by partial curve matching and electronically iterated using WINRESIST 1.0 computer iteration program. 


\section{RESULTS AND DISCUSSION}

\section{Depth Sounding Curves and Geoelectric Sections}

Four (4) different types of sounding curves (Figures $3 \mathrm{a}-\mathrm{d}$ ) were obtained from the study area, these include the 3-layer $(\mathrm{H})$; the 4-layer $(\mathrm{KH})$ and the 5-layer (KHA and $\mathrm{HKH})$ types. The $\mathrm{KH}$ type is predominant in the area. Details of the geoelectric parameters of each VES is presented in Table 1.

The very low/ low resistivity $(18-135 \mathrm{ohm}-\mathrm{m})$ characteristics observed on the Control VES (Figure 3c) which was established on the dumpsite depicts the nature of the wastes deposited on the dumpsite. As seen on the surface, the materials are majorly composed of metal scraps and other types of wastes. The geolectric column of the control VES point (Figure 4) delineated five geoelectric layers. The first layer is the topsoil and it has a thickness of $0.5 \mathrm{~m}$ and resistivity of 34 ohm-m. The second, third and fourth layers are typical of weathered layer and they are characterised by a resistivity range of between 18 and $135 \mathrm{ohm}-\mathrm{m}$ and a thickness range of 1.1 to $11.6 \mathrm{~m}$. The weathered layer is a significant aquifer unit in a typical basement complex environment (Olorunfemi, 2009; Ademilua and Eluwole, 2013; Obasi et al, 2013; Eluwole and Ademilua, 2014 etc.) and the resistivity of the layer plays a vital role in the nature of the aquifer.

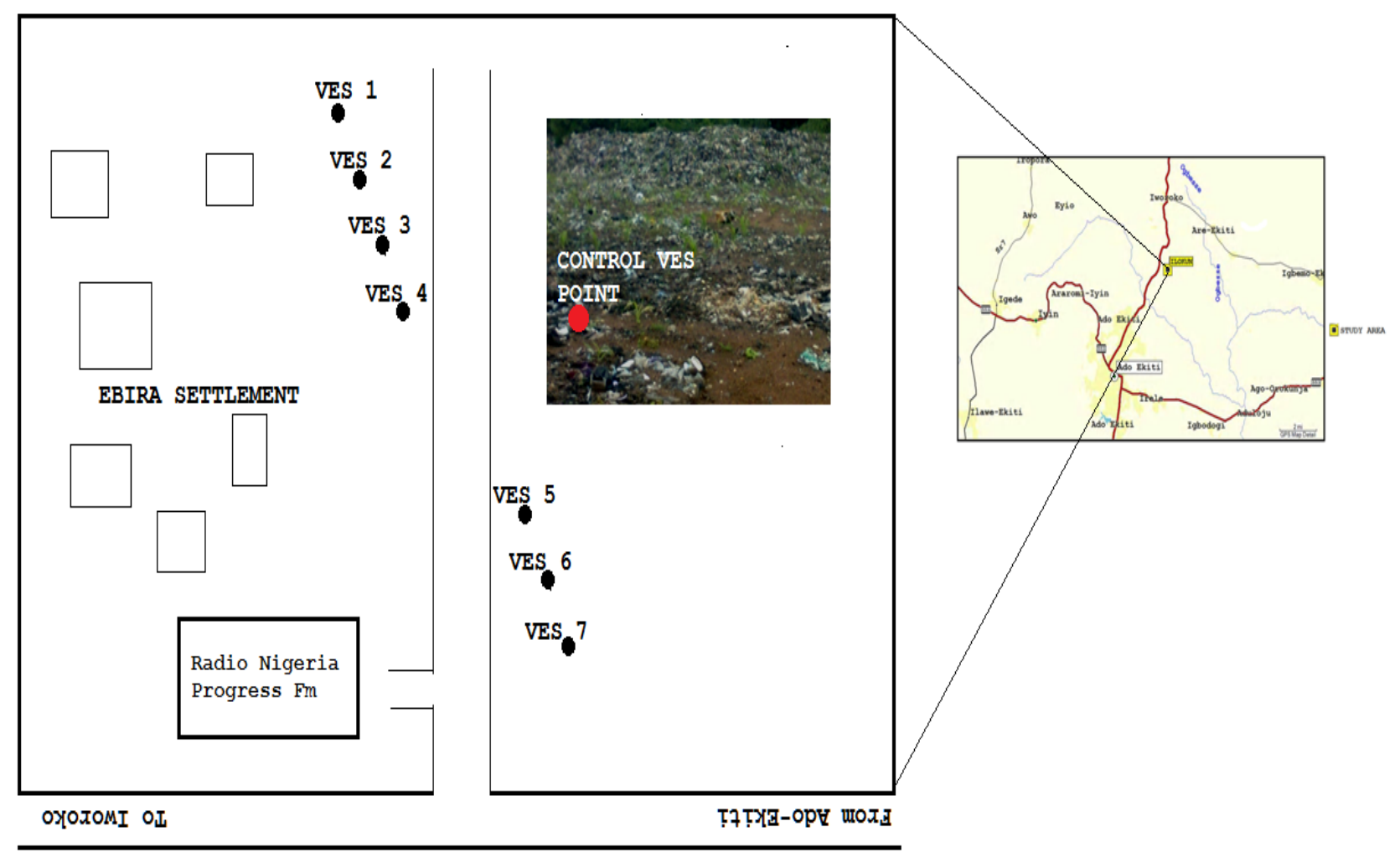

Figure 1: Geophysical Data Acquisition/Location Map of the Study Area. 


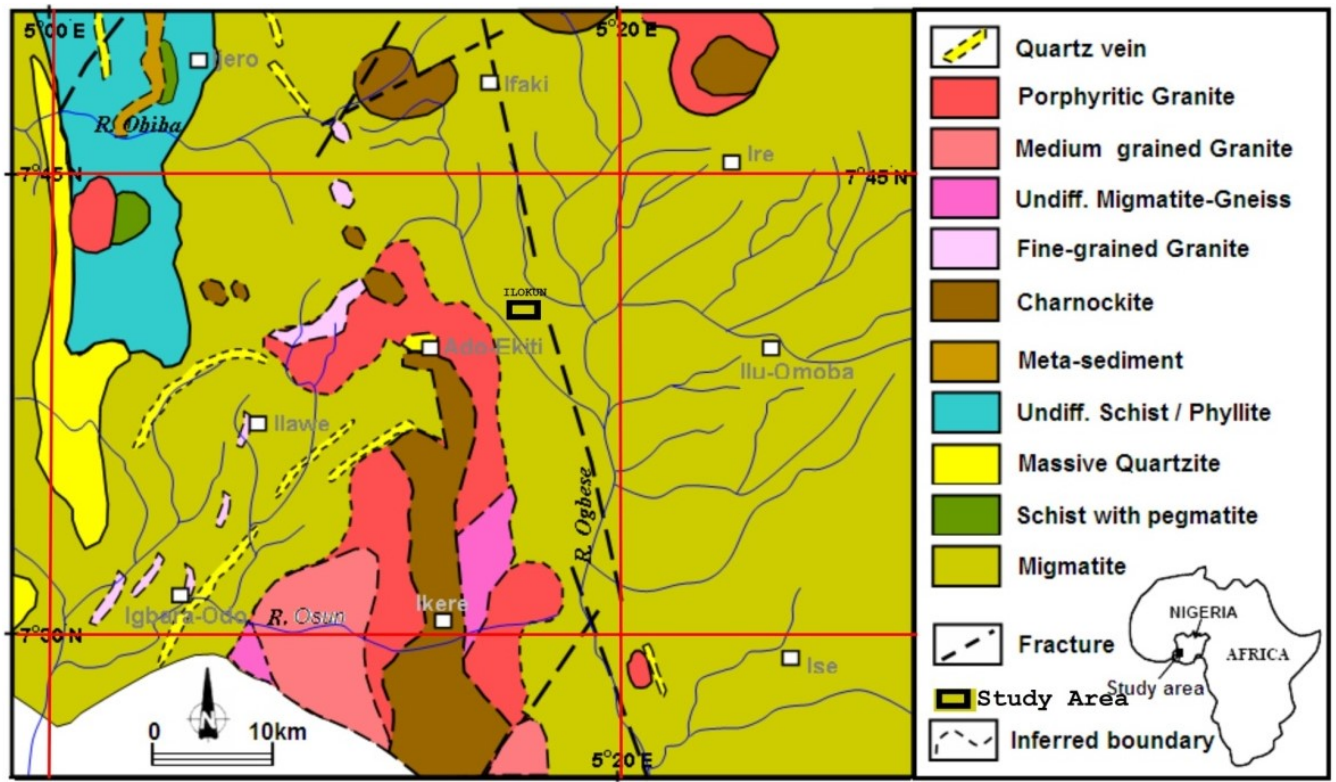

Figure 2: Geological Map of the Area Around Ado-Ekiti, Showing the Study Area (Adapted from Akure Sheet 56 Geological Map).
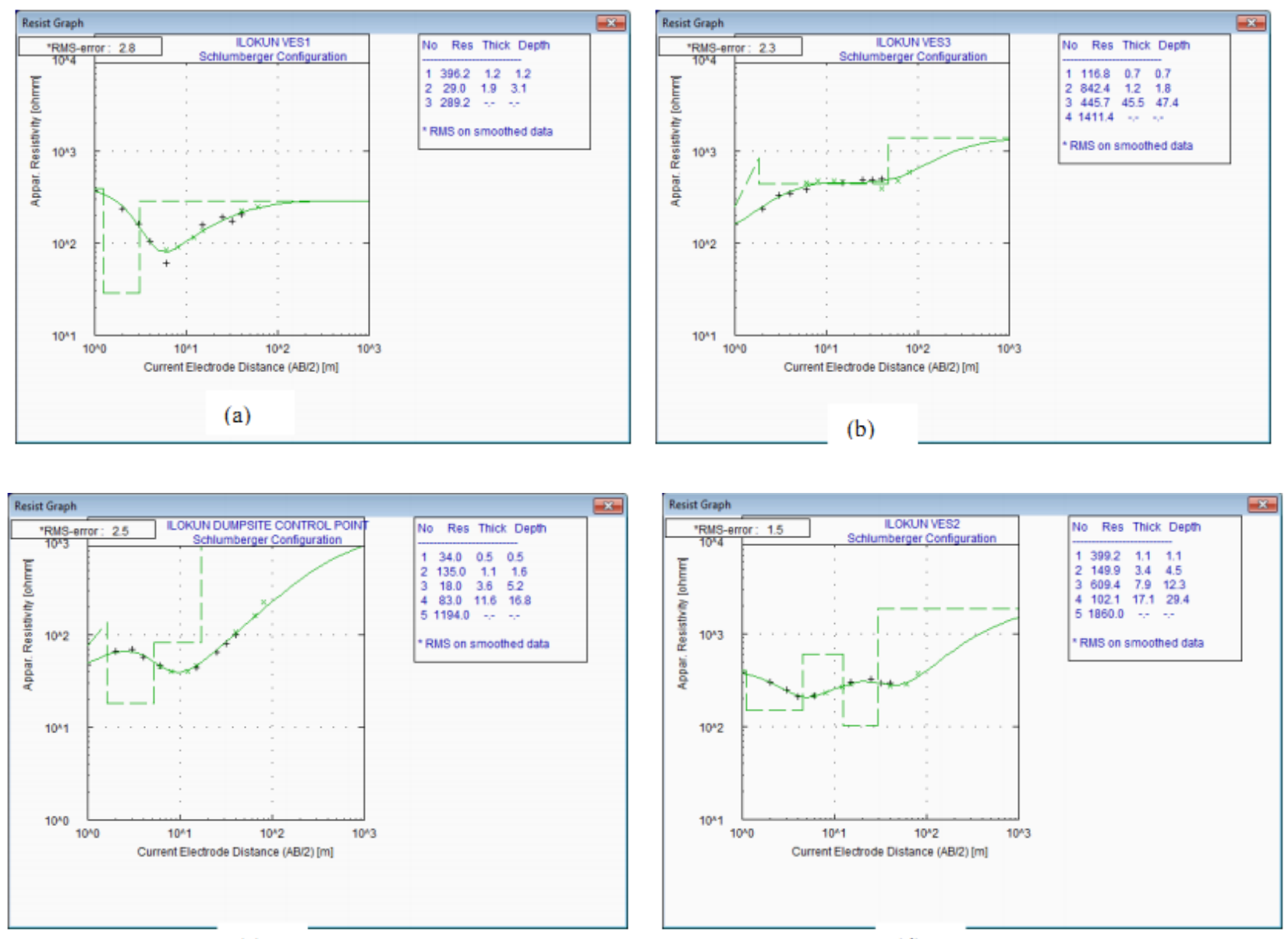

(c)

(d)

Figure 3. Resistivity Sounding Curves Obtained from the Study Area. (a) H-Type (b) KH-Type (c) KHA-Type and (d) HKH-Type 
Table 1: Summary of the Geoelectric Characteristics of the Study Area

\begin{tabular}{|c|c|c|c|c|c|}
\hline $\begin{array}{c}\text { VES } \\
\text { Stn. }\end{array}$ & $\begin{array}{c}\text { No. of } \\
\text { Layers }\end{array}$ & $\begin{array}{c}\text { Resistivity (Ohm-m) } \\
\rho_{1} / \rho_{2} / \ldots \rho_{n-1}\end{array}$ & $\begin{array}{c}\text { Curve } \\
\text { Type }\end{array}$ & $\begin{array}{c}\text { Thickness } \\
(\mathbf{m}) \\
h_{1} / h_{2} / \ldots h_{n-1}\end{array}$ & $\begin{array}{c}\text { Depth } \\
(\mathbf{m}) \\
d_{1} / d_{2} / \ldots d_{n-1}\end{array}$ \\
\hline Control & 5 & $34 / 135 / 18 / 83 / 1194$ & KHA & $0.5 / 1.1 / 3.6 / 11.6$ & $0.5 / 1.6 / 5.2 / 16.8$ \\
\hline 1 & 3 & $396 / 29 / 289$ & H & $1.2 / 1.9$ & $1.2 / 3.1$ \\
\hline 2 & 5 & $399 / 150 / 609 / 102 / 1860$ & HKH & $1.1 / 3.4 / 7.9 / 17.1$ & $0.7 / 1.8 / 47.4$ \\
\hline 3 & 4 & $117 / 842 / 446 / 1411$ & KH & $0.7 / 1.2 / 45.5$ & $0.7 / 1.8 / 47.4$ \\
\hline 4 & 5 & $151 / 42 / 1405 / 47 / 2142$ & HKH & $0.9 / 1.0 / 2.8 / 7.0$ & $0.9 / 1.9 / 4.7 / 11.7$ \\
\hline 5 & 4 & $124 / 660 / 16 / 408$ & KH & $1.1 / 1.0 / 4.7$ & $1.1 / 2.1 / 6.8$ \\
\hline 6 & 4 & $228 / 1499 / 37 / 2144$ & KH & $0.5 / 1.1 / 13.1$ & $0.5 / 1.6 / 14.7$ \\
\hline 7 & 4 & $356 / 570 / 33 / 1999$ & $\mathrm{KH}$ & $0.5 / 3.4 / 8.3$ & $0.5 / 3.9 / 12.2$ \\
\hline
\end{tabular}

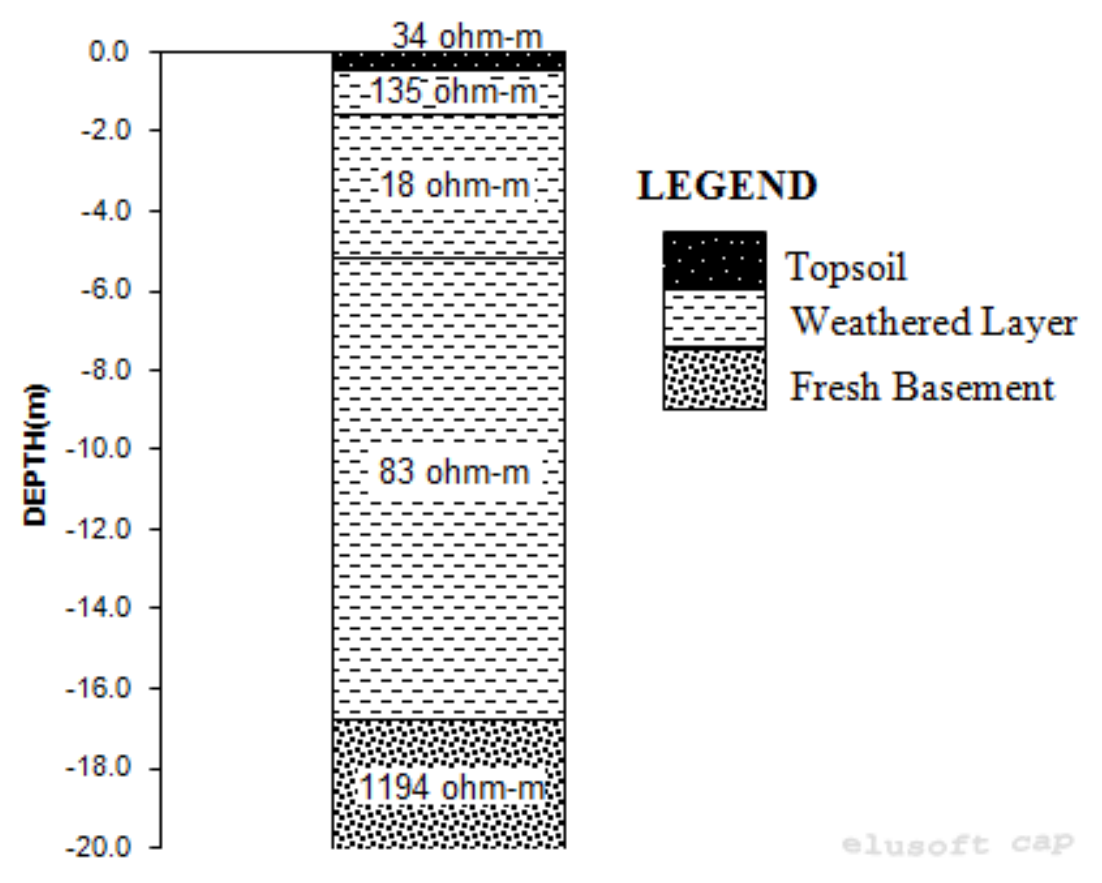

Figure 4: Geoelectric Column Beneath the Control VES Point

The very low resistivity zone $(18 \mathrm{ohm}-\mathrm{m})$ within the aquifer unit beneath the control VES is suggestive of the presence of conductive contaminant plume emanating from the dumpsite. The resistivity of the sub-surface material observed is also a function of the magnitude of the current, the recorded potential difference and the geometry of the electrode array used.

The geoelectric section (Figure 5) was generated from the geoelectric parameters (thicknesses and resistivities) obtained from the remaining seven (7) VES points. Four geoelectric layers were delineated and these include the topsoil; the weathered layer; the fractured basement and the fresh basement. The resistivity and thickness of the topsoil varies fro 117 to $399 \mathrm{ohm}-\mathrm{m}$, while the thickness is between 0.7 and $1.2 \mathrm{~m}$. The weathered layer has a resistivity range of between 29 and $842 \mathrm{ohm}-\mathrm{m}$ and the thickness range is 1.0 to $3.4 \mathrm{~m}$. The fresh basement rock beneath the topsoil and the weathered layer has a resistivity range of 570 to $1405 \mathrm{ohm}-\mathrm{m}$ and thickness of between 1.0 and $7.9 \mathrm{~m}$. The fractured basement which constitutes another aquifer unit in the area has resistivity and thickness range of 16 to $446 \mathrm{ohm}-\mathrm{m}$ and 4.7 to $45.5 \mathrm{~m}$ respectively. The basal fresh bedrock is infinitely thick and its resistivity is between 289 and $2144 \mathrm{ohm}-\mathrm{m}$. 
Having established from the interpretation of the Control VES point that the contaminant plume is conductive in nature, it is pertinent to note that a portion of the fractured basement identified as the aquifer unit in the surrounding of the dumpsite has been polluted with the contaminant plume emanating from the dumpsite.

The polluted zone characterised by anomalously low resistivity of between 16 and $47 \mathrm{ohm}-\mathrm{m}$ is present within the fractured basement beneath VES 4, 5, 6 and 7 respectively. The resistivities of the overlying layers around the polluted zone is relatively high and portrays no evidence of pollution, this suggests that the mode of migration of the contaminant plume may not be vertical. The migration may be structurally controlled by the interconnectivity of nearby fractured/sheared zones that have been polluted.

\section{CONCLUSION}

Solid waste disposal is considered as one of the main environmental problems, most of the generated solid waste amount to household waste and is buried in landfill or dumpsite. The dumped solid waste produce large amount of leachate which is a potential harm to both human and environment and likely contaminate groundwater. This would adversely affect industrial and agricultural activities that depend on groundwater. This study conducted electrical resistivity investigation on Ilokun dumpsite, Ado-Ekiti, via eight (8) vertical electrical sounding measurements.

The anomalously low resistivity characteristics of the weathered layer beneath the Control VES point have been attributed to the presence of conductive contaminant plume. The anomalously low resistivity (16-47 ohm-m) within the fractured basement beneath VES 4, 5, 6 and 7 are evidences of pollution from the contaminant. The fractured basement beneath VES 2 and 3 which posses the characteristics of a good aquifer unit is under a threat of being contaminated due to its interconnection with the polluted fractured zones. The mode of migration of contaminant plumes was also identified to be independent of the layers overlying the polluted fractured basement.

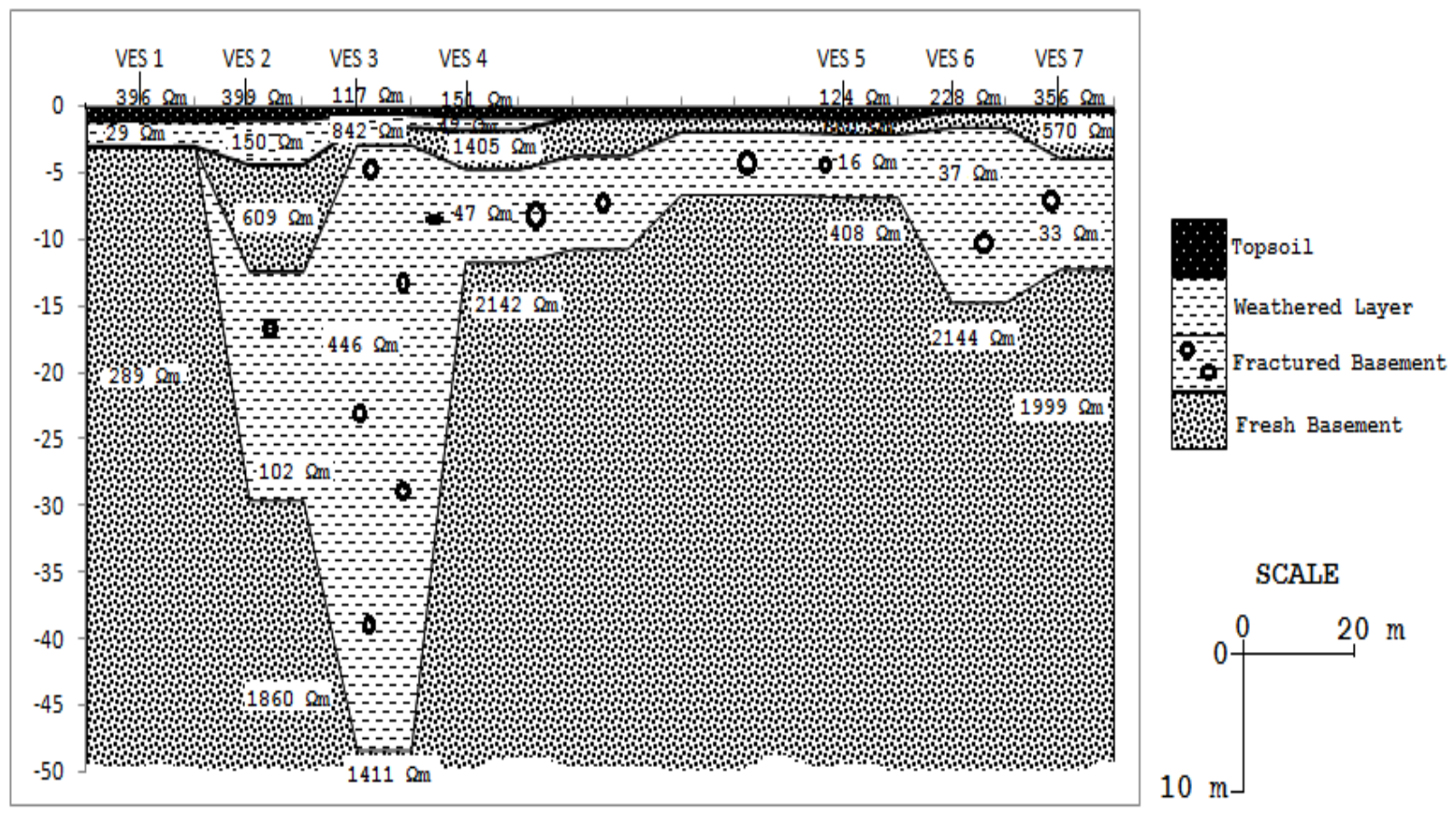

Figure 5: Geoelectric Section Beneath the Area Around Ilokun Dumpsite, Ado-Ekiti. 


\section{References}

[1] Ademilua, O.L. and Eluwole, A.B., 2013. Hydrogeophysical Evaluation of the Groundwater Potential of Afe Babalola University Ado-Ekiti, Southwestern Nigeria. Journal of Emerging Trends in Engineering and Applied Sciences. 4 (1): 77 - 83.

[2] Badmus, B.S., Odewande, A.A., Ojelabi, E.A. and Oyedele, Y. (2001): Leachate Contamination Effects on Groundwater Exploration. African Journal of Environmental studies. 2: 38 - 44 .

[3] Bou-Zeid E. and El-Fadel M. (2004). Parametric Sensitivity Analysis of Leachate Transport Simulations at Landfills. Science Direct, Waste Management, 24: 681-689.

[4] Eluwole A.B. and Ademilua O. L. (2014). Integrated Geophysical Investigations for the Development of a Sustainable Water Supply Scheme Within the Ekiti State University Campus, Ado-Ekiti, Southwestern Nigeria. International Journal of Scientific and Technology Research 3 (10): $294-304$

[5] Hussain, T., Hoda, A., and Khan, R. (1989): Impact of Sanitary Landfill on Groundwater Quality. Water, Air and Soil pollution 45: 191- 206.

[6] Ugwu, S A and Nwosu, J I (2009). Effect of Waste Dumps on Groundwater in Choba using Geophysical Method. Journal of Applied Sciences and Environmental Management 13(1): $85-89$

[7] Obasi, R.A., Ademilua O.L., and Eluwole A.B. (2013). Geoelectric Sounding for Groundwater Potential Appraisal Around the Northeastern - Southwestern Parts of the Federal Polytechnic Ado - Ekiti Campus, Southwestern Nigeria. Research Journal in Engineering and Applied Sciences. 2(3): 211-219.

[8] Ogwueleka, T.C., (2003). Analysis of Urban Solid Waste in Nsukka, Nigeria. Journal of Solid Waste Technology and Management. 29(4): 239-246.

[9] Olorunfemi, M.O., (2009). Groundwater Exploration, Borehole Site Selection and Optimum Drill Depth in Basement Complex Terrain. Water Resources, Special Publications Series 1, ISSN 0795-6495. 20p.

[10] Rahaman, M.A., 1988. Recent Advances in the Study of the Basement Complex of Nigeria. (Edited by Nigeria Geological Survey), pp. 11-43. 